Fastabiq: Jurnal Studi Islam

ISSN 2723-0228

Volume 1 Nomor 1 Juni 2020

Halaman 20-42

\title{
SIRAH NABAWIYYAH SEBAGAI PERJALANAN TASYR'I (Sebuah Pendekatan Etnografis di Indonesia)
}

\author{
Fabian Fadhly Jambak \\ Fakultas Hukum, Universitas Islam Bandung \\ fabianfadhly@ymail.com
}

\begin{abstract}
The journey of life of the Messenger of Allah influences and forms the Shari'a. Ethnography in the Arabian peninsula (especially Mecca and Medina) influenced the development of Islam in the time of the Prophet, especially Mecca with trade culture and Medina culture agriculture. The Shari'a is influenced by the ethnographic situation in the Arabian peninsula, especially in the holy cities of the Islamic Community, namely Mecca and Medina. Ethnography can influence the development of Islam in the time of the Prophet, especially the Mecca that developed form exchanges of information by traders while the Islamic Medina developed from areas that were culturally derived from agricultural societies. The uniqueness of ethnography and his life's journey refer to tashri (sharia) in terms of interpretation. Ethnography also influences the growth and development of Islam in Indonesia, which makes Islam acculturate with local culture. This paper is put forward as an effort to show the sirah nabawiyah (the journey of the Prophet's life) as one aspect of sharia formation, influenced by various factors in the spread, growth and development both in the Mecca and Madinah regions, as centers of Islamic teachings and Indonesia which has social differences, cultural, political and economic. The method put forward in this paper is the historical method, with the specification of a library research approach that refers to primary and secondary sources. Ethnography is one of the factors that can influence religious teachings to spread, grow and develop, a reality that also takes place on Islamic teachings. The teachings are influenced by the conditions of Mecca and Medina in shaping the law (tasyri). The teachings of Islam in Indonesia are spread and developed and grow sourced from the commercial activities carried out by the Arabian Peninsula in the 7th century AD, but trade does not dwarf the agricultural community that simultaneously embraces Islam, which at the same time also the community of agricultural communities trade with the spreaders of Islam in the Coast region.
\end{abstract}

Keywords: Ethnography, Indonesia, Nabawiyyah, Sirah, Tasyr'i.

\begin{abstract}
Abstrak
Perjalanan hidup Rasulullah saw mempengaruhi dan membentuk syariat. Etnografi di Jazirah Arab (khususnya Mekah dan Madinah) mempengaruhi perkembangan Islam di masa Rasulullah, khususnya Mekah dengan kultur perdagangan dan Madinah berkultur pertanian. Keunikan etnografi dan perjalanan hidup beliau berpengaruh pada tasyr'i (syariat) dalam hal penafsiran. Etnografi pun berpengaruh pada pertumbuhan dan perkembangan Islam di Indonesia, yang menjadikan Islam berakulturasi dengan budaya lokal. Tulisan ini dikedepankan untuk menunjukkan sirah nabawiyah sebagai salah satu aspek pembentukan syariat, dipengaruhi banyak faktor dalam penyebaran, pertumbuhan dan perkembangnnya di Mekah dan Madinah (pusat kelahirannya) maupun Indonesia yang memiliki perbedaan secara sosial, kultural, politik dan perekonomian.Metode yang dikedepankan dalam tulisan ini adalah metode historis, dengan pendekatan penelitian kepustakaan yang mengacu pada sumber primer dan sumber sekunder. Etnografi merupakan salah satu faktor yang dapat mempengaruhi proses penyebaran, tumbuh, dan perkembangan ajaran Islam. Ajaran Islam ini dipengaruhi kondisi etnografi serta kultural Mekah dan Madinah dalam membentuk hukum (tasyr'i). Ajaran Islam di Indonesia disebarkan dan berkembang dan bertumbuh bersumber dari kegiatan perniagaan yang dilakukan masyarakat Semenanjung Arab pada abad $7 \mathrm{M}$, akan tetapi perdagangan tidak mengkerdilkan komunitas pertanian yang secara bersamaan memeluk agama Islam, yang secara bersamaan pula komunitas masyarakat pertanian melakukan perdagangan dengan penyebar agama Islam di wilayah Pantai.
\end{abstract}

Kata Kunci: Ethnography, Indonesia, Nabawiyyah, Sirah, Tasyr'i 


\section{Fastabiq: Jurnal Studi Islam}

ISSN 2723-0228

Volume 1 Nomor 1 Juni 2020

\section{PENDAHULUAN}

Perjalanan kehidupan Rasulullah saw menunjukkan Islam sebagai sebuah ajaran yang mengandung nilai-nilai kemuliaan muncul bersamaan dengan rendahnya kualitas aqidah manusia pada saat itu di Semenanjung Arab merupakan daerah yang jauh dari peradaban dunia yang berpusat di Persia dan Romawi, India, dan Yunani. Persia adalah ladang subur berbagai khurafat keagamaan dan bermacam filsuf yang saling bertentangan, Romawi telah dikuasai sepenuhnya oleh semangat kolonialisme yang mempertentangkan antara agama dan negara. India berada pada kerusakan akhlak dan eksploitasi ekonomi. Yunani sebagai salah satu peradaban maju pada saat itu mengalami kondisi yang sama, khurafat dan mitos-mitos verbal yang tidak memiliki manfaat menjadi bagian dari kejayaan Yunani pada saat itu. ${ }^{1}$

Firas al-Khateeb mengungkapkan bahwa Hijaz menjadi wilayah munculnya ajaran Islam sebagai penerus agama Nabi Ibrahim as. Wilayah ini berada di Semenanjung Arab yang memiliki kondisi daerah yang kering, dikeliling oleh gunung yang tidak memberikan lingkungan untuk ditempati, serta memiliki temperatur suhu yang tinggi. Kondisi yang tidak menguntungkan bagi manusia untuk hidup tidak lantas Allah swt melepaskan kasih sayangnya untuk mengutus Rasul terakhir yang menbawa ajaran tauhid ke Semenanjung Arab. Nabi Muhammad saw merupakan Rasul terakhir yang membawa risalah tersebut, sosok Nabi Muhammad saw merupakan manusia yang terjaga dari penyimpangan-penyimpangan akidah yang lazimnya terjadi pada saat itu melalui ajaran politeisme. Keterjagaan ini sejak Nabi Muhammad saw belum diutus sebagai nabi rasul, yang digambarkan nabi sebagai penganut ajaran hanif atau ajaran tentang monoteis. ${ }^{2}$

Kepribadian ini pula yang menunjukkan Nabi Muhammad saw sebagai manusia agung dan sangat mengesankan tumbuh berkembang dan bersama dengan bertambah usianya. Ali ibn Thalib ra pernah memberikan komentar tentang kemuliaan akhlak yang dimiliki oleh Nabi Muhammad saw: "Pertama kali bertemu Nabi setiap orang akan terpesona melihat dirinya. Dan semakin dekat seseorang mengenal dirinya, maka orang itu akan semakin mencintainya." ${ }^{3}$ Saat Nabi Muhammad saw hadir di tengah kaum muslim setiap permasalahan yang terjadi pada saat itu, baik permasalahan dalam bidang kehidupan sosial maupun bidang keagamaan, diselesaikan atau dipecahkan melalui peran Nabi Muhammad saw sebagai utusan Allah swt yang memberikan jawab atas pertanyaan masyarakat itu melalui petunjuk wahyu. Wahyu tidak menjadi satu-satunya pertimbangan Rasulullah saw dalam setiap permasalahan adakalanya penyelesaian permasalahan tersebut diperoleh dari pemikiran dan pendapatnya atau melalui musyawarah dengan para sahabat. Pemikiran dan pendapat Nabi Muhammad saw dijumpai dalam hadits. ${ }^{4}$

Jawaban-jawaban yang muncul dari berbagai realitas kehidupan Nabi Muhammad saw, baik bersumber dari al-Quran dan al-Hadits muncul selaras dengan geografis sebuah peristiwa yang memerlukan jawaban atas pertanyaan yang muncul dari realitas tersebut. Jawaban-jawaban yang termasuk di dalamnya mengenai tasri', lekat geografis yang menunjukkan pentingnya suatu hukum bersinergi dengan keadaan tempat atau di wilayahnya. 


\section{Fastabiq: Jurnal Studi Islam \\ ISSN 2723-0228}

Volume 1 Nomor 1 Juni 2020

Letak geografis yang memungkinkan muncul perubahan-perubahan yang berbeda dalam menafsirakan dan menerpakan ajaran Islam, terutama terkait dengan penafisiran yang bersifat furu'iyyah tidak bersifat ushuliiyah. Penafsiran furu'iyyah yang berbeda acap kali ditemukan di beberapa wilayah dengan letak geografis yang berbeda dengan letak wilayah tempat asal usul dari agama Islam turun dan berkembang di tanah yang dulu dikenal dengan daerah Hijaz, dan saat ini dikenal dengan Kerajaan Arab Saudi.

Pengaruh geografis terhadap Islam di wilayah Asia Tenggara, termasuk di dalamnya pengaruh yang dominan di Indonesia dengan penguatan kearifan lokal di dalamnya. Salah satu contoh adalah islamisasi dari kawasan Asia Tenggara ini membawa persamaan di bidang pendidikan. Pendidikan tidak lagi menjadi hak istimewa kaum bangsawan. Tradisi pendidikan Islam melibatkan seluruh lapisan masyarakat. Setiap Muslim diharapkan mampu membaca Alquran dan memahami asas-asas Islam secara rasional dan dan dengan belajar huruf Arab diperkenalkan dan digunakan di seluruh wilayah dari Aceh hingga Mindanao. Bahasa-bahasa lokal diperluasnya dengan kosa-kata dan gaya bahasa Arab. Bahasa Melayu secara khusus dipergunakan sebagai bahasa sehari-hari di Asia Tenggara dan menjadi media pengajaran agama. Bahasa Melayu juga punya peran yang penting bagi pemersatu seluruh wilayah itu. ${ }^{5}$

Keunikan yang kemudian menjadi ciri khas bagi bangsa Melayu di Asia Tenggara, yang dasarnya memiliki berbagai macam bahasa dan kebudayaan, akan tetapi bahasa melayu dirintis oleh pusat-pusat kekuasaan Islam sebagai bahasa komunikasi dan kesusastraan, telah menjadi bahasa kebudayaan di kawasan ini, dan saat ini menjadi bahasa nasional bagi Malaysia maupun Indonesia. Bahasa melayu banyak berbaur dengan istilah-istilah Arab dan terpengaruh oleh gaya-gaya kesusastraan Islam klasik, baik Arab maupun Persia. ${ }^{6}$

Kawasan Asia Tenggara merupakan kawasan Melayu secara umum, walaupun terdapat etnis lain yang mendiami wilayah di Asia Tenggara. Dunia kebudayaan Melayu membentang dari Malaysia, Indonesia sampai ke Filipina Selatan (Kepulauan Mindanao). Wilayah ini merupakan kawasan kebudayaan yang berdasarkan etnolingusitik sangat luas dan beragam. Sekalipun secara etnologis penduduk di kawasan ini lebih homogen pada etnis Melayu, namun dalam kenyataan realitas sosial dan budayanya yang berkembang di dalamnya menunjukkan keragaman, atau heterogen. Islam dalam kawasan Melayu ini mempunyai perjalanan panjang terhadap proses Islamisasi berbagai etnis baik etnis Melayu maupun etnis lain yang berdiam diri di wilayah Melayu. ${ }^{7}$

Khusus bagi Indonesia pengaruh geografis tersebut dapat ditemukan dalam penyebaran ajaran Islam dengan menggunakan bahasa-bahasa lokal yang dikenal dengan model arsip nusantara sebagaiman yang diutarakan oleh Zacky Khairul Umam, sebagai sebuah pergerakan mengembalikan ajaran Islam yang menitikberatkan pentingnya tulis menulis yang bersifat dokumentatif. ${ }^{8}$ Zacky Khairul Umam lebih lanjut mengungkapkan tradisi yang patut ditiru generasi muda untuk terus mempelajari tradisi lokal yang sering dilupakan berdasarkan sumber-sumber, arsip, aksara, dan pengetahuan lokal yang marginal atau sengaja dipinggirkan, dengan jenjang pendidikan sebagai sarana untuk menghormati otoritas keilmuan dan tidak mencederai apa yang sudah dicapai dalam sistem pendidikan Islam zaman klasik. ${ }^{9}$ 


\section{Fastabiq: Jurnal Studi Islam \\ ISSN 2723-0228}

Volume 1 Nomor 1 Juni 2020

Adopsi merupakan kata yang tepat dalam menerjemahkan tradisi tulis menulis Islam terhadap penduduk lokal Indonesia, sebagai salah satu cara yang dapat digunakan dalam melakukan penafsiaran terhadap furu'iyyah. Sebuah yang dilakukan oleh para penyebar Islam dapat menduduki berbagai jabatan dalam struktur birokrasi kerajaan dan diantara mereka ada yang kawin dengan penduduk setempat. Kemudian mereka mendirikan Mesjid, mengadopsi kebudayaan lokal menjadi bermuatan Islam, mendidik kader ulama, mengislamkan raja dan keluarganya dan pendekatanpendekatan sosial lainnya sesuai dengan kondisi dan situasi setempat. Dengan kata lain bahwa Islam menjadi kokoh di pusat-pusat kekuasaan Nusantara melalui jalur perdagangan, perkawinan dengan elit birokrasi dan ekonomi, diskusi keagamaan, dan sosialisasi langsung dengan masyarakat bawah. ${ }^{10}$

Adopsi yang muncul dari pergumulan berbagai hubungan yang dibangun dari perdagangan, perkawinan dan sosialiasi masyarakat merupakan bagian yang sama dengan Islam pada era Nabi Muhammad saw, akan tetapi hubungan yang muncul di Indonesia tidak menghadapi pertentangan yang berat layaknya pada masa awal Islam muncul di wilayah Semenanjung Arab. Penerimaan yang lebih halus dari masyarakat Indonesia dimungkinkan menjadi sebab Islam dinilai mudah menjadi bagian dari masyarakat Melayu termasuk di Indonesia. Refleksi dari ajaran Islam yang menitikberatkan pada perkembangan manusia atau faktor-faktornya. Sebuah ajaran yang bertujuan untuk menempatkan akhluq yang dinamakan manusia sebagai khalifah fi al-ardh, dengan mengedepankan fungsi Islam sebagai rahmatan li al-amin.

Keduanya menunjukkan pengaruh yang akan muncul pada setiap keadaan manusia yang memiliki perbedaan dalam etnografis wilayah dan sosial kemasyarakatan bagi masyarakat melayu dengan terjadi perubahan kebudayaan dan peradaban Melayu, baik dari segi gagasan (ideofak), aktivitas (sosiofak), dan benda (artefak). Sejarahwan berpendapat, bahwa Islam masuk ke Nusantara (Indonesia) abad $7 \mathrm{M}$, atau abad $11 \mathrm{M}$, dan berkembang pesat pada abad 13 dapat diterima dengan mudah oleh bangsa Melayu karena karakternya yang egaliter dan populis. Islam tidak mengenal sistem kasta dan kependetaan, sehingga memungkinkan keterlibatan semua lapisan masyarakat dalam seluruh aspek kehidupan. Faktor lain adalah karena penyebaran agama Islam didukung oleh tiga kekuatan, yaitu istana, pesantren dan pasar. ${ }^{11}$

\section{METODE PENELITIAN}

Tahapan-tahapan dalam metode penelitian sejarah dengan pengumpulan bahan-bahan tertulis dan lisan yang relevan, mengenyampingkan bahan-bahan dari sumber yang tidak autentik, menyimpulkan kesaksian yang dapat dipercaya berdasarkan bahan-bahan autentik, dan penyusunan kesaksian yang dapat dipercaya itu menjadi suatu kisah atau penyajian yang berarti, dapat diperinci sebagai berikut:

Pertama, tahap heuristik. Tahap ini merupakan kegiatan yang dilakukan dalam pencarian dan pengumpulan data serta fakta. Tahapan ini mengumpulkan fakta-fakta yang bersumber dari data yang relevan terutama dokumen, baik sumber primer maupun sekunder yang dapat digunakan dalam menjawab keterkaitan Sirah Nabawiyyah dengan tasyr'i. Kedua, tahap Kritik sumber yang terdiri dari 


\section{Fastabiq: Jurnal Studi Islam \\ ISSN 2723-0228}

Volume 1 Nomor 1 Juni 2020

eksternal dan internal. Tahap eksternal berhubungan dengan sumber yang digunakan merupakan sumber data yang berada satu masa dengan peristiwa sejarah tersebut, atau setidaknya mampu menunjukkan hubungan yang nyata. Adapun tahap internal terkaitan dengan substansi (isi) dari sumber data yang sejalan (selaras) dengan peristiwa yang menjadi objek penilitan dalam hal ini tasyri pada masa Nabi Muhammad saw. Ketiga, tahap Penafsiran atau interpretasi yang berhubungan dengan upaya untuk mengekstraksi peristiwa yang terdapat dalam dokumen-dokumen tertulis dapat memiliki makna atau arti. Keempat, tahap histrografi yaitu penulisan hasil penelitian. Historiografi adalah rekontruksi yang imajinatif dari periode lampau berdasarkan data yang diperoleh dengan menempuh proses Penulisan laporan disusun berdasarkan serialisasi (kronologis, kausasi dan imajinasi), yang secara langsung memiliki hubungan dengan syariat di era Nabi Muhammad saw.

Sumber merupakan titik tolak suatu penelitian sejarah dikatakan sebagai sebuah disiplin ilmu, yang mengedepankan fakta baik itu bersumber dari dokumen, audio, maupun visual. Pencarian dan penemuan sumber dalam upaya untuk memberikan gambaran secara lebih jelas mengenai hubungan yang terjalin antara perjalanan Nabi Muhammad saw dengan kehidupan keagamaan yang bersifat syariat di masanya. Secara ideal gambaran tersebut dapat didasari kepada dua sumber yaitu: sumber primer sebagai acuan utama dalam upaya menunjukkan hubungan etnografis memiliki pengaruh yang berhubungan langsung dengan perubahan-perubahan terhadap tasyr'i pada Nabi Muhhamd saw dan sumber sekunder sebagai pelengkap dan penguatan bagi materi yang dirujuk dari sumber primer.

Sumber Primer yang digunakan sebagai acuan dapat dirinci sebagai berikut:

1. al-Quran;

2. al-Hadits;

3. Muhammad Said Ramadhan al-Buthi, Fiqh as-Sirah an-Nabawiyyah ma'a Mawjazi at-Tarikh alKhilafat ar-Rasyidin, Dar as-Salam, Kairo, 1999.

4. Ali Musthafa al-Farabi, Tarikh al-Firqu al-Islami wa Nasyatu 'IIma al-Kalama 'Inda al-Muslimin, Maktabah al-Akhbalu al-Masharriyah, 1975.

5. Khursid Ahmad, Islam: Prinsip-Prinsip Dasar Dan Karakteriisti-Karakteristiknya dalam Pesan Islam (terj. Achsin Mohammad), Pustaka, Bandung, 1983.

6. Firas al-Khateeb, Lost Islamic History Reclaiming Muslim Civilisation From The Past, Hurst Publisher, London, 2014.

7. Shafiyu ar-Rahman al-Mubarakafury, Rahiq al-Makhtum Bahtsun Fi as-Sirah an-Nabawiyyah 'ala Shahibuha Afdhalu as-Shalatu wa as-Salam, Dar al-Wafa, Mansurah, 2002.

8. Shalih Ahmad ats-Tsamy, Min Ma'in as-Sirah, al-Maktab al-Islamy, Beirut, 1984.

9. Ajid Thohir, Sirah Nabawiyah (Nabi Muhammad saw dalam Kajian Ilmu Sosial dan Humaniora), Marja, Bandung, 2014.

Sumber Sekunder yang digunakan sebagai acuan dapat dirinci sebagai berikut:

1. Ajid Thohir, Studi Kawasan Dunia Islam: Perspektif Etno-Linguistik Dan Geo-Politik, Rajawali Pers, Jakarta, 2011. 


\section{Fastabiq: Jurnal Studi Islam}

ISSN 2723-0228

Volume 1 Nomor 1 Juni 2020

2. Asep Achmad Hidayat, Studi Kawasan Muslim Minoritas Asia Tenggara, Pustaka Rahmat, Bandung, 2017.

3. Muhammad Khudari Bek, Tarikh Tasyri' al-Islamy, Dar al-Kutub al-Ilmiyyah, Beirut, 2013.

4. Zakiyy al-Din Syu`ban, Usul al-Fiqh al-Islami, Mu`assash `Ali as-Sibah, Kuwait, 1988.

Rujukan lain yang berisi informasi-informasi syariat di masyarakat Nabi Muhammad saw, yang secara khusus dapat ditemukan dalam kitab-kitab klasik yang secara berkelanjutan dikutip dalam setiap kitab-kitab ulama-ulama kontemporer. Pemanfaatan kedua rujukan utama ini tidak menafikan penggunakan rujukan buku-buku yang digunakan, baik buku yang berbahasa asing yang diterjemahkan maupun buku-buku berbhasa Indonesia yang relevan dengan pembahasan artikel yang mencoba menggali koneksitas Sirah Nabawiyyah dengan tasyr'i.

Metode penelitian sejarah diperkuat dengan teori gerak siklus sejarah (Ibnu Khaldun) Pada teori ini Ibnu Khaldun berpendapat bahwa teori ilmu sejarah berkaitan dengan kebudayaan. Pikiran Ibnu Khaldun menunjukan bahwa kebudayaan adalah masyarakat manusia yang didasarkan atas hubungan manusia dan alam di satu sisi dan hubungan manusia dengan manusia lainnya, ${ }^{12}$ tetapi jika dilihat secara lebih mendalam, sejarah merupakan penalaran kritis (nadhar) dan usaha cermat untuk mencari kebenaran. Sejarah merupakan penjelasan cerdas tentang sebab-sebab dan asal-usul segala sesuatu. la merupakan pengetahuan mendalam tentang bagaimana dan mengapa suatu peristiwa itu terjadi. Definisi sejarah tentang demikian membawa Ibnu Khaldun untuk berpendapat bahwa sejarah itu berakar dalam filsafat (hikmah). Oleh karenanya, la pantas dipandang sebagai bagian dari filsafat itu sendiri. ${ }^{13}$

Teori yang muncul dari Muqaddimah sebuah karya yang paling berpengaruh dari Ibnu Khaldun. Hal ini dianggap sebagai upaya pertama oleh setiap sejarawan untuk mengungkap struktur dalam perubahan dan perkembangan yang berdampak pada kehidupan masyarakat dan kelompok masyarakat yang menawarkan interpretasi peristiwa sejarah, filsafat sejarah. Muqaddimah menawarkan penjelasan tentang struktur hubungan manusia dalam kaitannya dengan lingkungan dan sejarah dengan menandakan: ${ }^{14}$

... Muqaddimah adalah pencapaian ilmiah ranking tinggi. Meskipun banyak kekurangan, Muqaddimah, dalam konsepsi dan eksposisi, jauh melampaui segala sesuatu yang telah dikatakan tentang budaya manusia sampai saat Ibnu Khaldun; dan itu adalah peringkat yang sama dengan karya modern yang berkaitan dengan masalah serupa.

Muqaddimah meliputi sebagian besar ide dan kontribusi filosofis yang paling terkenal dari Ibn Khaldun. Meskipun termasuk banyak referensi untuk peristiwa sejarah, ilmu ekonomi, pendidikan, dan bidang lain, implikasi sosiologis telah menjadi subyek pengawasan meningkat dan ini merupakan bidang minat kita dalam makalah ini. Referensi Ibnu Khaldun untuk kepemimpinan datang dalam konteks analisis tentang bagaimana masyarakat berkembang. Dalam menulis tentang masyarakat manusia, ia mengeksplorasi alasan mengapa orang membutuhkan kepemimpinan politik. Meskipun ide-idenya secara dominan menekankan kepemimpinan politik dalam entitas sosial, kesimpulannya dapat diperluas untuk mencakup kepemimpinan dalam berbagai pengaturan organisasi. Dalam 


\section{Fastabiq: Jurnal Studi Islam}

ISSN 2723-0228

Volume 1 Nomor 1 Juni 2020

rangka untuk mengeksplorasi gagasan kepemimpinannya, pandangannya tentang sifat manusia layak mendapat perhatian khusus. Kemudian kita mengeksplorasi pandangannya tentang perlunya kepemimpinan, sifat kekuatan pemimpin dan perilaku kepemimpinan.

\section{PEMBAHASAN}

\section{Sirah}

Karakteristik yang muncul pada diri Nabi Muhammad saw merupakan gambaran dari kesucian nasab (garis keturunan) yang dimilikinya. Karakteristik ini muncul mulai dari 'Abd al-Muthalib dengan nasab bersambung kepada Zuhrah ibn Kilab, sebagai pemuka kaum bani Zuhrah yang memiliki kemulian sebagai pemimpin pada saat itu. kesucian nasab dari Nabi Muhammad saw tidak terlepas dari pernikahan yang dilakukan oleh 'Abdullah sebagai keturunan dari 'Abd al-Muthalib dengan Aminah sosok wanita unggul dari kalangan suku Quraisy. ${ }^{15}$

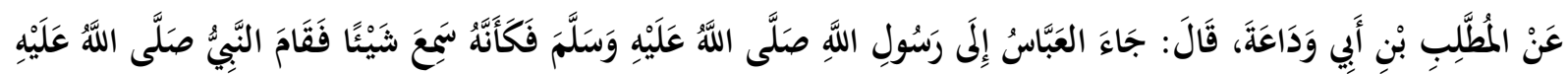

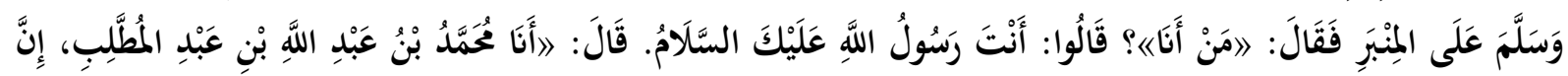

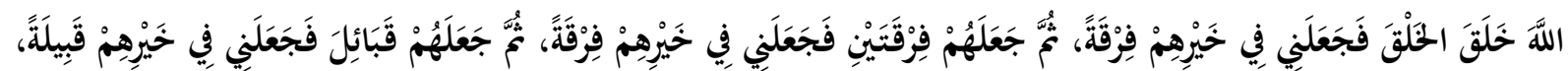

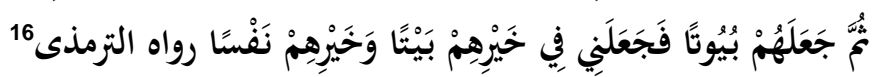

Nabi Muhammad saw sebagai sosok yang mulia merupakan pembawa riaslah ketauhidan yang selaras dengan para Rasul sebelumnya, sehingga Rasulullah saw digelari sebagai penutup para Nabi sesuai dengan hadits yang diriwayatkan oleh Bukhari dan Muslim:

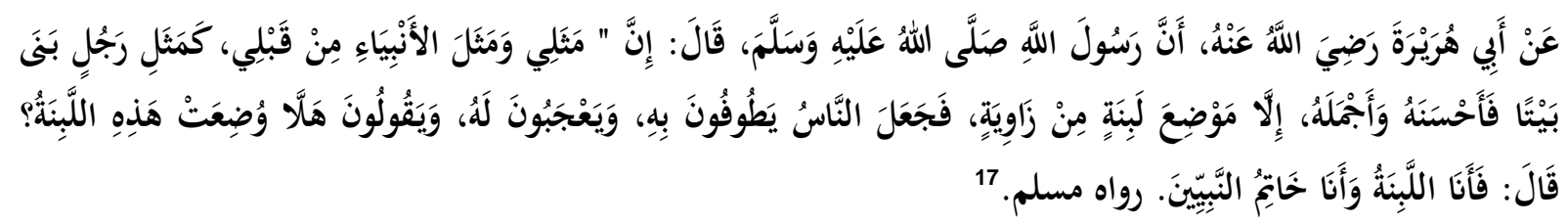

Sirah Nabi Muhammad saw adalah wujud hidup dari ajaran-ajaran Islam sebagaimana yang dinginkan Allah swt untuk diterapkan di alam nyata. Ajaran Islam tidak diturunkan untuk dikurung di dalam tembok-tembok masjid atau di dalam aula bangunan sekolah agama dan perguruan-perguruan tingginya, tetapi diturunkan Yang Maha Bijaksana lagi Maha Mengetahui untuk menjadi tingkah laku manusia dan metode kehidupan yang dihayati setiap muslim pada diri dan kepribadiannya serta dapat dilihat dalam melalui kenyataan individu dan masyarakat. inilah yang didapati dalam sirah Nabi Muhammad saw mewujudkan ajaran-ajaran Islam sebagaimana yang dikehendaki Allah swt untuk diterapkan dalam kehidupan dan kemanusiaan, dalam segala situasi dan kondisi dirinya. ${ }^{18}$

Sirah merupakan upaya menyelami kehidupan Nabi Muhammad saw yang dalam rangkaian kehidupannya mengandung makna dalam mengenai ajaran Islam. Islam bukan hanya ditempatkan sebagai ajaran tanpa sebab-akibat maupun tujuan akan turusan risalah ini. Sirah menunjukkan Rasulullah saw sebagai bentuk kehidupan manusia yang dibimbing wahyu Illahi bukan hanya untuk 


\section{Fastabiq: Jurnal Studi Islam \\ ISSN 2723-0228}

Volume 1 Nomor 1 Juni 2020

hanya untuk menunjukkan kekuasaan Allah swt, melainkan memiliki tujuan dan fungsi memahami setiap perbedaan yang terdapat dalam masyarakat Islam dapat ditemukan jawaban terhadap perbedaan tersebut dengan merujuk kepada bagaimana Nabi Muhammad saw menjalani kehidupannya sebagai penerus risalah kenabian Nabi Ibrahim as. ${ }^{19}$

Sirah memiliki ruang lingkup yang luas tidak hanya berkaitan dengan kehidupan Rasulullah saw pada satu aspek bidang saja, melainkan memiliki berbagai macam ruang lingkup yang terdapat di dalamnya. Aspek-aspek kehidupan tersebut menyentuh bidang ibadah dan hukum, muamalat (ekonomi dan perekonomian), akhlak, pemerintahan. Sirah menuntun fase-fase yang terdapat dalam kehidupan Rasullaah saw diketahui oleh umat Islam setelahnya. Aspek hukum menjadi bagian yang tidak terlepas dalam memahami kehidupan pembawa risalah ketauhidan ini. Tarikh tasyr'i merupakan bagian dari sirah yang terkait dengan pembentukan (legislasi) hukum Islam, yang diawali pada periode Nabi Muhammad saw melalui turunnya wahyu sebagai penegas kenabiannya sampai dengan masa modern saat ini. ${ }^{20}$

Muhammad Said Ramadhan al-Buthi mengungkapkan bahwa tugas yang diemban oleh Rasulullah saw berkaitan dengan Aqidah (ketauhidan) dan yang kedua tasyri' (legislasi/pembentukan hukum) serta akhlak. Aqidah berkaitan dengan keimanan terhadap Allah swt, iman kepada hari kiamat, surga dan neraka, adapun Tasyri' terkait dengan penghapusan aturan-aturan hukum yang ditetapkan terdahulu pada kaum-kaum sebelum diutusnya Rasulullah saw sebagai nabi dan rasul. Penghapusan aturan hukum dikenakan terhadap aturan hukum agama samawi yang dikenal dengan syariatu man qablana. ${ }^{21}$

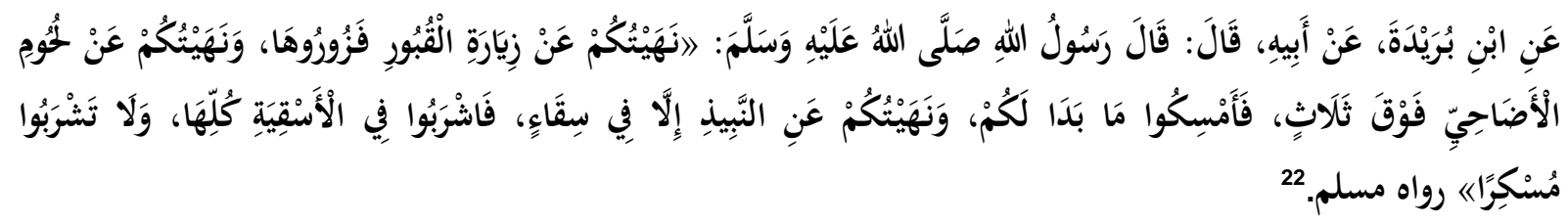

Keterkaitan Aqidah dalam risalah Rasulullah saw adalah penguatan Islam sebagai agama yang hak di pandangan Allah swt mulai dari risalah kenabian Nabi Adam as sampai dengan Nabi Muhammad saw, sebagai mana termaktub dalam al-Quran:

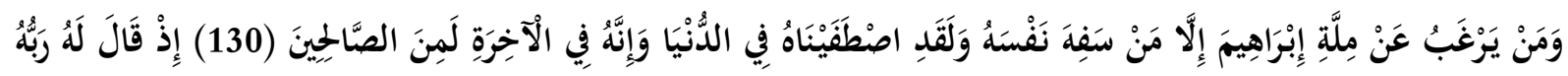

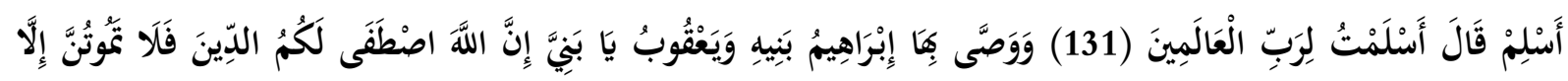

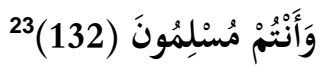

130. dan tidak ada yang benci kepada agama Ibrahim, melainkan orang yang memperbodoh dirinya sendiri, dan sungguh Kami telah memilihnya[90] di dunia dan Sesungguhnya Dia di akhirat benarbenar Termasuk orang-orang yang saleh. 131. ketika Tuhannya berfirman kepadanya: "Tunduk patuhlah!" Ibrahim menjawab: "Aku tunduk patuh kepada Tuhan semesta alam". 132. dan Ibrahim telah Mewasiatkan Ucapan itu kepada anak-anaknya, demikian pula Ya'qub. (Ibrahim berkata): "Hai anak-anakku! Sesungguhnya Allah telah memilih agama ini bagimu, Maka janganlah kamu mati kecuali dalam memeluk agama Islam".

Tasyri bermula dengan penegasan Nabi Muhammad saw melalui kegiatan tahannuts di Gua Hira yang dimulai dengan turunnya surat al-'Alaq 1-5, pewahyuan ini terjadi di Mekah sebagaimana 


\section{Fastabiq: Jurnal Studi Islam}

ISSN 2723-0228

Volume 1 Nomor 1 Juni 2020

Gua Hira berada. Keluarga dekat merupakan sasaran dakwah Islam berdasarkan wahyu yang diterima Rasulullah saw yaitu surat:

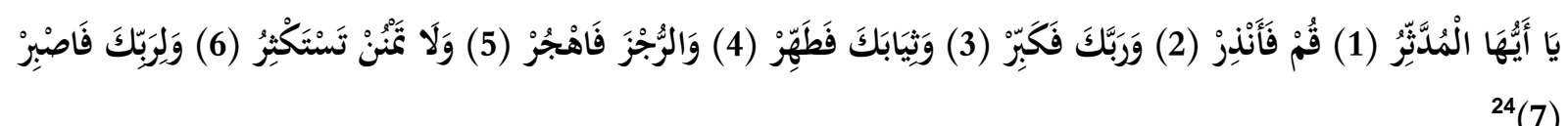

1. Hai orang yang berkemul (berselimut), 2. bangunlah, lalu berilah peringatan! 3. dan Tuhanmu agungkanlah! 4. dan pakaianmu bersihkanlah, 5. dan perbuatan dosa tinggalkanlah, 6. dan janganlah kamu memberi (dengan maksud) memperoleh (balasan) yang lebih banyak. 7. dan untuk (memenuhi perintah) Tuhanmu, bersabarlah.

\section{Tasyr'i}

Pengertian tasyri tidak terlepas dengan kata syari'ah yang memiliki dua makna secara bahasa dan istilah. Secara bahasa kata ini menunjukkan kepada kata benda dengan arti berjalan yang menunjukkan air mengalir untuk minum dan mengairi sesuatu, sedangkan menurut istilah kata ini diartikan sebagai apa-apa yang telah ditetapkan Allah swt untuk mematuhi setiap hukum-hukum yang datang bersamaan dengan Nabi saw yang menjadi bagian dari para nabi yang didalamnya terkandung tatacara suatu perbuatan yang dinamai dengan far'iyyah dan 'amaliyyah dan termasuk di dalamnya ilmu fiqih atau terkait dengan pelaksanaan aqidah, dan ada pula yang dinamai dengan ushuliyyah dan i'tiqadiyah termasuk di dalamnya ilmu kalam. Kedua aspek tersebut bagi orang mu'min dapat membantu dalam kehidupan mereka di duni adan akhirat. ${ }^{25}$

Tasyri awal kenabian dan kerasulan Rasulullah saw berkaitan dengan materi-materi dari ajaran Islam yang terdapat dalam al-Quran dan al-Hadits. al-Quran pada periode ini merupakan kitab yang diturunkan secara berangsur-angsur bermula pada hari ketujuh belas ramadan tahun 41 Masehi yang disampaikan ketikan di Gua Hira. al-Hadits merupakan segala sesuatu yang disandarkan kepada Nabi Muhammad saw, baik itu peerkataan, perbuatan atau persetujuan, tidak ada keraguan bahwa ketiganya merupakan penyampaian dari Allah swt: ${ }^{26}$

\section{Periode Mekah}

Tasyri' di Mekah secara umum menerangkan permasalahan-permasalah mengenai ajaran ketauhidan menjauhi perbuatan keji, dan tercela. Pembunuhan, perilaku buruk terhadap perempuan, menghormati hak asasi manusia, menghindarkan diri dari perilaku licik, dan curang dalam bermuamalat seperti mengurangi timbangan atau takaran. Zakat dan sadaqah telah diperkenalkan di Mekah, periode ini ditekankan pada pada kesadaran bermasyarakat dan solidaritas sesama ${ }^{27}$

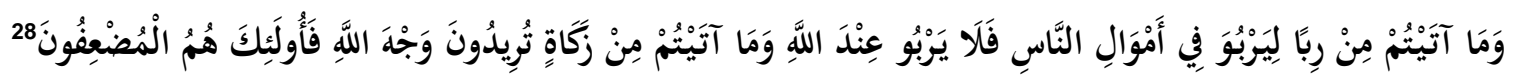

"dan sesuatu Riba (tambahan) yang kamu berikan agar Dia bertambah pada harta manusia, Maka Riba itu tidak menambah pada sisi Allah. dan apa yang kamu berikan berupa zakat yang kamu maksudkan untuk mencapai keridhaan Allah, Maka (yang berbuat demikian) Itulah orang-orang yang melipat gandakan (pahalanya)."

Tauhid mengajarkan bahwa seluruh fenomena lahiriah misalnya siang dan malam, lautan dan daratan, matahari, bumi, manusia dan seluruh makhluk hanyalah ayat atau tanda-tanda kekuasaan 


\section{Fastabiq: Jurnal Studi Islam}

ISSN 2723-0228

Volume 1 Nomor 1 Juni 2020

Allah swt yang menunjukkan adanya tauhidul wujud (kesatuan eksistensi). Tauhidul wujud ini sekaligus menunjukkan bahwa tidak perlu ada kontradiksi atau disharmoni antara manusia dan alam, jasmani dan ruhani, dunia dan akhirat, juga antara substansi dan makna. Tauhid berfungsi antara lain mentransformasi setiap individu yang menyakininya menjadi manusia yang lebih kurang ideal dalam arti memiliki sifat-sifat mulia dengan pertama, memiliki komitmen utuh pada Tuhannya, dengan secara maksimal menjalankan pesan dan perintah Allah swt sesuai dengan kemampuan yang ada. Kedua, menolak pedoman hidup yang datang bukan dari Allah swt. pengertian ini dalam konteks masyarakat manusia. Ketiga, bersikap progresif denga selalu melakukan penilai terhadap kualitas kehidupan, adat-istiadat, tradisi dan paham hidupnya. Bila dalam penilainya ternyata terdapat dimensi syirik muncul kesediaan dalam dirinya untuk menyesuaikan dengan pesan Illahi. Keempat, kejelasan tujuan hidup. Ibadah, kerja keras, hidup dan mati ditujukan hanya untuk Allah swt semata. Kelima, kehidupan dibangun dengan keselarasan antara hubungan vertikal dengan Tuhan dan hubungan horizontal antara sesama manusia yang memusatkan pada perhatian dari usaha dan gerakan umat tidak terbatas pada suatu masyarakat atau bangsa tertentu, tetapi meluas pada seluruh kemanusiaan. ${ }^{29}$

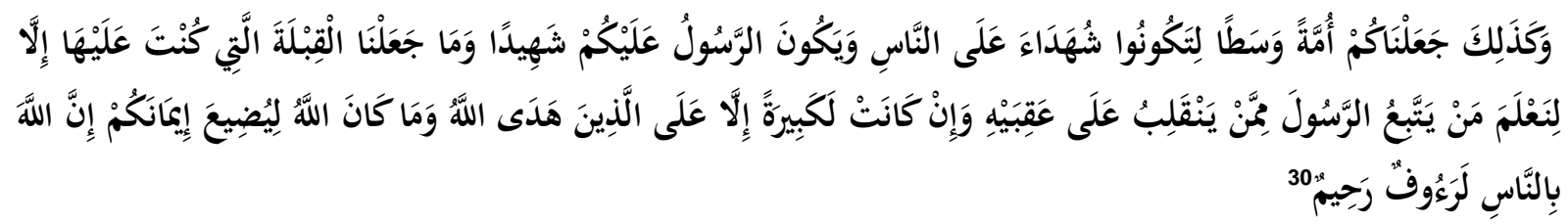

dan demikian (pula) Kami telah menjadikan kamu (umat Islam), umat yang adil dan pilihan agar kamu menjadi saksi atas (perbuatan) manusia dan agar Rasul (Muhammad) menjadi saksi atas (perbuatan) kamu. dan Kami tidak menetapkan kiblat yang menjadi kiblatmu (sekarang) melainkan agar Kami mengetahui (supaya nyata) siapa yang mengikuti Rasul dan siapa yang membelot. dan sungguh (pemindahan kiblat) itu terasa Amat berat, kecuali bagi orang-orang yang telah diberi petunjuk oleh Allah; dan Allah tidak akan menyia-nyiakan imanmu. Sesungguhnya Allah Maha Pengasih lagi Maha Penyayang kepada manusia.

Dakwah Nabi Muhammad saw yang menyeru kepada Islam dianggap sebagai perusakan terhadap tatanan masyarakat yang dianut oleh kalangan bangsawan. Inilah yang menyebabkan terjadinya banyak konflik. Sikap kontra tersebut tidak sekedar dilatarbelakangi faktor sosial dan faktor ekonomi saja. Para bangsawan belum siap untuk menyejajarkan kedudukannya dengan sekelompok masyarakat yang selama ini merupakan budak. Selain itu adanya larangan menyembah berhala tidak saja berdampak dalam hal kepercayaan, tapi juga dampak ekonomi. Hal ini karena pembuatan berhala merupakan salah satu penghasilan masyarakat saat itu. ${ }^{31}$

Mustafa Ahmad al-Zarqa mengungkapkan melalui kepercayaan akan keesaan Allah swt yang memiliki sifat-sifat kesempurnaa, Islam berusaha membersihkan akal budi manusia dari kotoran pemujaan berhala dan angan-angan yang berbau tahayul. Salah satu manifestasi dari usaha-usaha ini adalah bahwa Islam tidak mengizinkan melakukan shalat di depan kuburan, dan juga melarang orang bersumpah dengan sesuatu selain Allah swt. Ritualitas-ritualitas keagamaan dilakukan dengan yuridiksi kesesuai dengan kehendak-Nya, termasuk pemuasaan kesenangan-kesenangan yang halal dengan melaksanakan kewajiban yang telah digariskan oleh al-Quran dan al-Hadits. Kewajibankewajiban itu adalah sarana-sarana utama untuk memperkuat ikatan manusia dengan Allah swt, 


\section{Fastabiq: Jurnal Studi Islam}

ISSN 2723-0228

Volume 1 Nomor 1 Juni 2020

landasan ini yang menjadi dasar ritual ibadah yang diwajibkan seperti salat, puasa, zakat dan haji tidak boleh ditinggalkan. ${ }^{32}$

Djaka Soetapa dengan jelas memberikan gambaran bahwa Nabi Muhammad saw menganjurkan adanya equalitas dan fraternitas antara manusia dan semua itu disatukan dalam Islam dengan memunculkan istilah ummah, dengan disertai pengajaran yang dimunculkan terkait dengan dakwah terhadap kaum Quraisy. Dakwah yang dilakukan Rasulullah saw dihadapi oleh Quraisy dengan sikap pertentangan yang dilukiskan dengan brutality and recalcitrance dan sikap pertentangan kepada Nabi Muhammad saw dilukiskan dengan coarseness and lack of veneration. ${ }^{33}$ Ahmad Syalabi mengungkapkan ada lima faktor yang menyebabkan orang/kaum Quraisy termotivasi untuk menentang seruan ajaran Islam yang dirisalahkan melalui wahyu: ${ }^{34}$

a. Mereka tidak dapat membedakan antara kenabian dan kekuasaan

b. Nabi Muhammad Saw. mendakwahkan persamaan hak antara bangsawan dan hamba sahaya.

c. Para pemimpin Quraisy tidak dapat menerima ajaran tentang kebangkitan kembali dan pembalasan di akhirat.

d. Taklid kepada nenek moyang yang sudah berakar pada bangsa Arab.

e. Pemahat dan penjual patung memandang Islam sebagai penghalang rezeki.

\section{Periode Madinah}

Madinah adalah sebuah oasis pertanian, bagaimana Mekah, Madinah merupakan perkampungan yang disibukan oleh konflik horisontal yang sengit dan anarkis antara kelompok sukusuku terpandang, diantaranya Aus dan Khazraj. Konflik yang berkepanjangan itu membuat rakyat kecil selalu merasa tidak aman dan menimbulkan permasalahan eksistensial di Madinah. Selanjutnya berbeda dengan Mekah, Madinah senantiasa mengalami perubahan sosial yang meninggalkan bentuk kemasyarakatan absolut model Badui. Kehidupan sosial Madinah secara berangsur-angsur diwarnai oleh unsur kedekatan ruang daripada unsur kekerabatan. Yang jelas, Madinah memiliki sejumlah warga Yahudi yang sebagian besar pengikutnya lebih simpati terhadap monoteisme. W. Montgomery Watt dalam bukunya "Muhammad Propet and State Man" menjelaskan kondisi sosial politik Madinah sebelum peristiwa hijrah. Watt menulis bahwa keadaan di Madinah berbeda dengan keadaan di Mekah. Di Mekah dan daerah sekitarnya tidak ada lahan pertanian, konsekuensinya eksistensi kota tersebut tergantung pada perdagangan. ${ }^{35}$

Madinah sebagai tempat hijrah dengan disertai Nabi Muhammad saw yang tidak hanya menempatkan dirinya sebagai pemimpin kaum muslimin, melainkan sebagai peletak dasar dari aturan-aturan hukum yang dirisalahkan oleh Allah swt dengan memberikan pemahaman-pemahaman yang mendalam terkait dengan ajaran Islam yang berbeda dengan ajaran Islam ketika di Mekah, keyakinan akan kebenaran penyampaian aturan yang ditetapkan al-Quran melalui Rasulullah saw menjadi sebuah keniscayaan, perbedaan-perbedaan dalam memahami setiap ayat bermuara pada dirinya, keadaan ini terus berlanjut sampai meninggalnya Nabi Muhammad saw. ${ }^{36}$ Madinah sebagai 


\section{Fastabiq: Jurnal Studi Islam}

ISSN 2723-0228

Volume 1 Nomor 1 Juni 2020

tempat hijrah kaum muslim merupakan tempat yang memiliki kedudukan yang mulia tergambarkan dengan hadits:

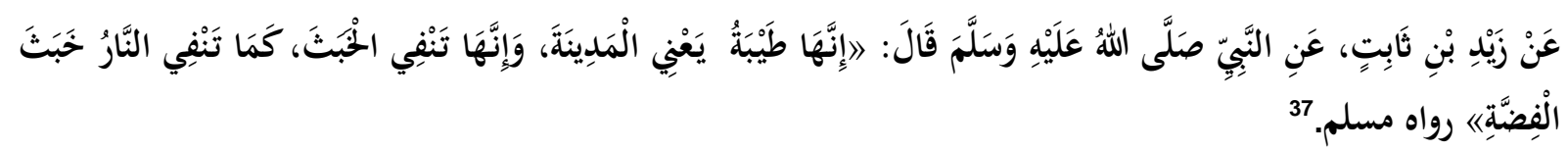

Hijrahnya Nabi Saw. ke Madinah merupakan periode yang kedua dalam pembinaan hukum Islam. Periode Madinah dikenal sebagai periode penataan dan pemapanan masyarakat. Oleh karena itu di periode Madinah inilah ayat-ayat yang memuat hukum-hukum mulai diturunkan baik yang bersifat ritual maupun sosial. Adapun faktor yang menyebabkan proyek hukum, banyak dibicarakan dalam periode Madinah yaitu karena dalam periode ini orang Islam sudah memiliki dasar akhlak dan aqidah yang kuat sebagai landasan terhadap aspek-aspek kehidupan masyarakat muslim lainnya. ${ }^{38}$

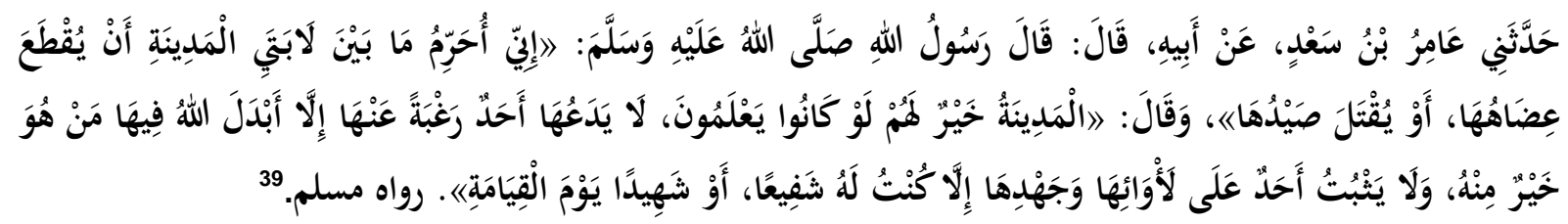

Periode ini ditandai dengan pengenalan awal berbagai sisi lain dari syariah Islam yang berupa peribadatan (ubudiyah), seperti salat, puasa, zakat, maupun haji. ${ }^{40}$ Termasuk pula disosialisasikan selama periode itu konsep jiha fi sabilillah (berjuang di jalan Allah swt), dalam arti sempit berupa berperang di jalan Allah melawan kaum kafir, yaitu mereka yang ingkar terhadap kebenaran Islam dan mengganggu umat Islam. ${ }^{41}$

Tasyri pada periode Madinah telah lengkap, tetapi sebagian besar lembaga-lembaga baru dalam tingkat permulaan. Salat belum dapat diatur secara penuh, sekalipun sudah mulai dilaksanakan termasuk di dalamnya salat malam telah sering dilakukan. Demikian juga dengan ajaran-ajaran Islam yang lain seperti puasa, zakat, syahadat, dan berhaji belum sepenuhnya dapat dilaksanakan, tetapi konsepsi pokok tentang Tuhan, hari akhir, surga dan neraka, adanya para nabi dan rasul, semua itu telah ditanamkan dengan kukuh. ${ }^{42}$

Madinah dalam masa pemerintahan Rasulullah saw mulai menegaskan pelaksanaan hukum, baik hukum pidana maupun perdata, sehingga rakyat merasa tenang dan tentram karena terlindungi hak-haknya, Bahkan, saat itu telah dibuat undang-undang pertama di negara ini yang menganut kehidupan masyarakat bernegara yaitu Piagam Madinah. ${ }^{43}$ Senada dengan hal ini Hunt Janin menyatakan Madinah pada periode ini sampai wafat Nabi Muhammad saw berkaitan dengan tradisi pembentukan hukum (tasyri') dan penyatuan kekuatan politik yang berada di Madinah, termasuk di dalamnya pertempuran-pertempuran yang terjadi pada saat itu. Perkembangan penting Madinah adalah dengan lahirnya Constitution of Medina (Piagama Madinah). ${ }^{44}$

Periode ini merupakan masa sebagian besar hukum syari'ah tentang masalah sosial dan ekonomi. Wahyu yang turun selama periode ini berfungsi memperkuat fondasi iman dan tauhid yang telah ditetapkan sejak periode Mekah, secara garis besar atau secara umum dapat dibuat empat kategori terkait dengan hal tersebut yaitu: ${ }^{45}$ 


\section{Fastabiq: Jurnal Studi Islam}

ISSN 2723-0228

Volume 1 Nomor 1 Juni 2020

a. Hukum-hukum

Turunnya wahyu mengenai tiga rukun Islam, selain larangan pada hal-hal yang memabukkan, daging babi, judi dan hukuman bagi pezina, pembunuhan dan pencurian.

b. Jihad

Periode Mekkah kaum muslim dilaraang mengangkat senjata untuk melawan orang-orang Makkah yang menekan mereka, demi menghindari berkurangnya jumlah dan meningkatkan kesabaran mereka. Hak untuk berperang menghadapi musuh-musuh dan juga aturan-aturab berperang diwahyukan di Madinah setelah jumlah pemeluk Islam bertambah banyak.

c. Ahli kitab

Di Madinah, untuk pertama kalinya kaum Muslimin berhubungan dengan Ahli Kitab, yaitu kaum Yahudi dan kaum Nasrani dalam skala besar. Karenya sejumlah ayat-ayat Madinah banyak menjawab pertanyaan-pertanyaan yang dikemukakan oleh orang-orang Yahudi untuk menguji Nabi Muhammad saw dan mendeskreditkan Islam.

\section{d. Kaum munafik}

Ada yang memeluk Islam dengan maksud berusaha menghancurkan Islam dari dalam karena kaum Muslim semakin kuat dan mereka tidak memiliki keberanian untuk menentangnya secara terbuka.

Manifestasi tasyr'i dalam periode ini menurut Wael B. Halaq dimulai dari turunnya ayat yang berkaitan dengan penyatuan komunitas yang berada di Madinah yaitu Islam, Nasrani dan Yahudi, dengan mengedepankan satu komunitas yang disebut dengan ummah. Legitimasi terhadap hal ini dimaktubkan dalam ayat berikut: ${ }^{46}$

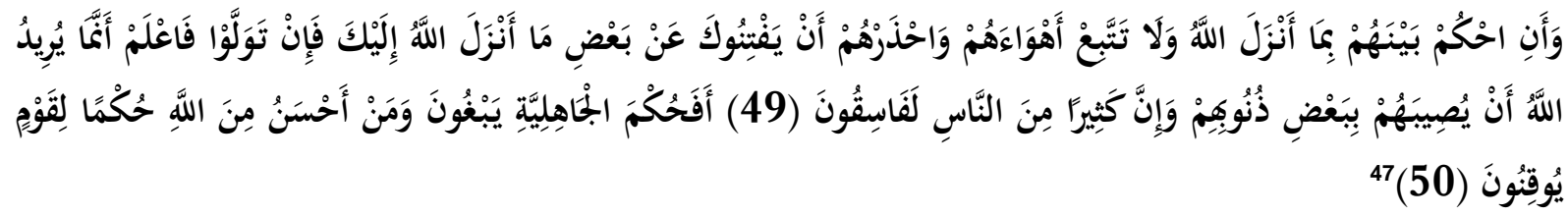

49. dan hendaklah kamu memutuskan perkara di antara mereka menurut apa yang diturunkan Allah, dan janganlah kamu mengikuti hawa nafsu mereka. dan berhati-hatilah kamu terhadap mereka, supaya mereka tidak memalingkan kamu dari sebahagian apa yang telah diturunkan Allah kepadamu. jika mereka berpaling (dari hukum yang telah diturunkan Allah), Maka ketahuilah bahwa Sesungguhnya Allah menghendaki akan menimpakan mushibah kepada mereka disebabkan sebahagian dosa-dosa mereka. dan Sesungguhnya kebanyakan manusia adalah orang-orang yang fasik. 50. Apakah hukum Jahiliyah yang mereka kehendaki, dan (hukum) siapakah yang lebih baik daripada (hukum) Allah bagi orang-orang yang yakin?

Perjuangan dan instruksi-instruksi konstruktif pada periode Mekah dilanjutkan dengan konstruktif-konstruktif yang lebih khusus dengan bagian al-Quran yang bersifat relatif, selain dari pernyataan-pernyataan yang mendetail tentang hukum waris dan hukuman bagi kejahatan-kejahatan seperti pencurian dan perzinaan yang tidak ditentukan dengan pasti secara hukum. alasan yang mendasar dari hukum yang relatif ini dikarenakan terdapat perintah-perintah khusus yang menyangkut 


\section{Fastabiq: Jurnal Studi Islam}

ISSN 2723-0228

Volume 1 Nomor 1 Juni 2020

perjuangan kaum Muslimin terhadap kelompok non-Islam dan hubungan dengan mereka, maka perintah-perintah tersebut bervariasi menurut situasi yang yang ada, walaupun keadaan itu menunjukkan tidak ditentukkannya makna khusus dalam pengertian hukum yang ketat. ${ }^{48}$

Respon terhadap kebutuhan masyarakat yang terus berkembang di Madinah dengan proses interaksi tiga komunitas yang berada di Madinah menuntut adanya wahyu yang menjawab atas kebutuhan-kebutuhan tersebut. respon terhadap perubahan menurut Abdullahi Ahmed an-Na'im tidak hanya berkaitan dengan kegiatan politik atau hukum melainkan perubahan makna dan implikasi alQuran dan Sunnah. Norma-norma politik dan hukum al-Quran dan Sunnah pad aperiode ini tidak selalu mencerminkan makna dan implikasi pesan yang pasti sebagaimana yang diwahyukan di Mekkah. $^{49}$

\section{Islam dan Indonesia}

Islam Asia Tenggara dalam pandangan Azyumardi Azra berbeda dengan Islam di Timur Tengah, perbedaan ini muncul dari hasil percampuran secara sosial, budaya, bahkan politik atau lebih dikenal adanya proses kompromisasi antara Islam Arab dengan tradisi lokal di Asia Tenggara. Ulama menjadi tonggak (pelopor) Islam menjadi bagian dari sebuah kebudayaan yang ada di Asia Tenggara, bukti nyata akan keadaan ini dimunculkan dengan ulama yang mengabdikan dirinya kepada Kesultanan-Kesultanan Islam di Aceh, Melaka dan Patani sebagai sebuah respon dari makna ummah sebagai penggambaran akan masyarakat yang dipimpin oleh Sultan. ${ }^{50}$ Osman Bakar berpandangan Islam muncul di wilayah Asia Tenggara bermula dari munculnya negara muslim pada tahun $1292 \mathrm{M}$ di Sumatera yang dipengaruhi oleh pandangan-pandangan ajaran Islam melalui pemahaman dan penafsiran yang disampaikan oleh Abu Hamid al-Ghzazali. ${ }^{51}$ Islam Asia Tenggara dalam pandangan tidak hanya bertumpu pada Indonesia, Malaysia dan Brunei Darusslam yang memiliki jumlah Muslim sebagai penduduk mayoritas, melainkan Myanmar menjadi bagian dari aktifitas Islam di Asia Tenggara yang didiami (ditinggali) mayoritas oleh penduduk etnis Melayu dan etnis Rohingya yang berasal dari wilayah Bengali. ${ }^{52}$

Islam abad ke $7 \mathrm{M}$ merupakan agama yang muncul dalam dominasi Kerajaan Sriwijaya di belahan Barat dan Kahuripan-Singasari di belahan Timur, masyarakat muslim di Indonesia telah menyebar di pantai-pantai dan pelabuhan penting Nusantara. Salah satu keuntungan dari konsepsi Islam ialah bahwa setiap muslim selain wajib melaksanakan setiap peribadatan juga diwajibkan untuk mengenalkan ajaran Islam kepada umat manusia. ${ }^{53}$ Syari'at Islam sejak kedatangannya ke Nusantara hingga saat ini merupakan hukum yang hidup (living law), tidak hanya pada tataran simbol, melainkan juga pada tataran praktis. Hal tersebut bukan semata-semata sebuah tanda bahwa mayoritas pemeluk agama di Indonesia adalah agama Islam, melainkan syari'at Islam dalam realitas alaminya di beberapa daerah sudah menjadi tradisi (adat) yang terkadang dianggap sakral. Secara sosiologis dan kultural, syari'at Islam merupakan hukum yang berurat dan berakar dalam budaya masyarakat. Hal ini disebabkan fleksibilitas dan elastisitas yang dimiliki syari'at Islam. Artinya meskipun ada kekuatan 


\section{Fastabiq: Jurnal Studi Islam \\ ISSN 2723-0228}

Volume 1 Nomor 1 Juni 2020

otonom yang terdapat dalam ketetapan Tuhan, namun syari'at Islam dalam realisasinya mampu melakukan upaya transformative-adaptif. ${ }^{54}$

Hamka mengemukakan bahwa sejarah panjang Islam berada di Indonesia dimulai pada abad VII M dengan berhijrahnya bangsa Arab melalui Samudera Hindia dan melalui jalan darat. Perkampungan-perkampungan yang didirikan oleh bangsa Arab menjadi bukti Islam telah masuk pada abad tersebut. Tempat singgah yang berada di rute perdagagan daerah Malabar dan pulau Sailan merupakan bukti Indonesia menjadi bagian dari perluasaan kekuasaan Bani Umayyah pada saat itu, melalui pendekatan ekonomi atau trannsaksi perniagaan. ${ }^{55}$ Perjalanan Islam memasuki wilayah Indonesia tidak lepas dari pengaruh kekuasaan Islam yang mengalami perluasan wilayah penyebarannya. Khulafa ar-Rasyidin merupakan pelopor ketercapaian hal tersebut, yang dilanjutkan oleh Dinasti Umayyah dan Dinasti Abbasiyah.

Mata rantai penyebaran Islam dari Semenanjung Arabia ke Indonesia beriringan dengan perkembangan lembaga pendidikan pada awal Islam terdiri dari dua tingkat: Tingkat pertama, yaitu maktab/Kuttab dan masjid, yaitu lembaga pendidikan terendah, tempat anak-anak mengenal dasardasar baca, tulis dan hitung, dan tempat para remaja belajar dasar-dasar ilmu agama, seperti tafsir, hadits, figh dan bahasa. Tingkat kedua, yaitu pendalaman, di mana para pelajar yang ingin memperdalam ilmunya, pergi ke luar daerah menuntut ilmu kepada para ahli dalam bidangnya masing-masing, umumnya ilmu agama. Pengajarannya berlangsung di masjid-masjid atau di rumahrumah ulama bersangkutan atau di istana bagi anak-anak penguasa dengan memanggil ulama ahlinya ke istana. ${ }^{56}$

Dua tingkatan sistem pendidikan ini mendapatkan pengaruh yang cukup besar dari Metode pengajaran Islam yang pernah dipraktekan pada masa pemerintahan Dinasti Abasiyah dapat dikelompokkan dalam tiga kategori yaitu metode lisan, tulisan, dan hafalan. Metode lisan berupa dikte, ceramah, qira'ah, dan diskusi. Metode imlak adalah metode yang dipakai dalam setiap tingkatan institusi pendidikan Islam klasik. Metode imlak berfungsi untuk menyampaikan pengetahuan yang dianggap baik dan aman karena anak didik mempunyai catatan, hal ini juga untuk membantu daya ingat anak yang kuat. Metode diskusi merupakan metode khas dalam pendidikan Islam klasik. Ulamaulama sering mengadakan majlis-majlis diskusi. Metode ini banyak digunakan dalam pengajaran ilmuilmu filsafat dan fiqih. Metode diskusi bertujuan melatih siswa mengamalkan ilmu dan menggunakan daya berfikir secara aktif, metode yang paling mudah untuk memperoleh penguasaan ilmu pengetahuan melalui latihan lisan guna mengungkap pikiran-pikiran dengan jelas dalam diskusi ilmiah. $^{57}$

Aceh menjadi tempat pertama Indonesia mengenal Islam pada abad 7, banyak mempengaruhi adat-istiadat Aceh. Pengaruh ini dibuktikan dengan pepatah yang berbunyi: Hukom ngo Adat lagee Zat ngo Sipheuet (hukum dengan adat seperti benda dengan sifatnya, tidah terpisah). Hukum di sini diartikan dengan hukum Islam yang diajarkan oleh para ulama. Ini ditunjukkan oleh pepatah lain yang berbunyi: Adata bak Meureuhom, Hukum Bak Syiah Ulama. ${ }^{58}$ Hukum Islam pada era ini mulai mewarnai kehidupan bangsa Indonesia, dengan fiqih yang berasal dari jazirah Arab dalam 


\section{Fastabiq: Jurnal Studi Islam \\ ISSN 2723-0228}

Volume 1 Nomor 1 Juni 2020

menentukan segala tindakan umat Islam. Fiqih walaupun telah diakui sebagai lembaga yang mengatur kehidupan masyarakat pada saat itu tidak menjadikannya sebagai kekuatan utama dalam pergaulan antar masyarakat. Tasawuf dan amalan tarekat yang menjadi kegiatan utama dalam pergaulan, pemimpin-pemimpin atau para guru suluk (sjujuch al-turuq) yang mendapatkan penghormatan dibandingkan ahli-ahli ilmu kalam (mutakallimun), maupun para ahli hukum (fuqaha). ${ }^{59}$

Islamisasi di Nusantara menggunakan pendekatan kultural sehingga mencitrakan cara-cara yang damai, sedangkan islamisasi di kawasan Timur Tengah menggunakan pendekatan militer berupa penaklukan sehingga mencitrakan kekerasan. Sementara itu, posisi kawasan Nusantara ini terkait dengan waktu proses Islamisasi. Fauzan Saleh menilai bahwa lantaran posisi geografis yang jauh dari pusat penyebaran Islam itu, Indonesia terlambat dalam mengikuti proses islamisasi. ${ }^{60}$ Perlambatan yang terjadi dalam tradisi intelektual Islam yang tidak terlihat pada zaman pertengahan di Indonesia, dapat dilihat dengan munculnya berbagai macam karya-karya sastra. Keadaan ini berbanding terbalik dengan pusat peradaban Islam zaman klasik yang dipelopori oleh keruntuhan Bagdad pada tahun 1258 oleh Hulagu Khan. ${ }^{61}$ Faktor-faktor yang menyebabkan perbedaan ini coba diungkapkan oleh Syarif: ${ }^{62}$

1) telah banyaknya Filsafat Islam (yang bercorak sufistis) yang dimasukkan al-Ghazali di Timur, demikian pula Ibnu Rusyd dalam memasukkan filsafat Islamnya (yang bercorak rasionalistis) ke dunia Islam di Barat yang akhirnya keduanya bermuara ke arah bidang rohaniah hingga menghilang dalam mega alam tasauf, sedangkan Ibnu Rusyd menuju ke jurang materialisme;

2) Umat Islam terutama para pemerintahnya (khalifah, sultan, amir-amir) melalaikan ilmu pengetahuan dan kebudayaan, dan tidak memberi kesempatan bidang-bidang tersebut untuk berkembang.

3) Terjadinya pemberontakan yang dibarengi dengan serangan dari luar, sehingga menimbulkan kehancuran-kehancuran yang mengakibatkan berhentinya kegiatan pengembangan ilmu pengetahuan dan kebudayaan di dunia Islam.

\section{SIMPULAN}

Etnografi merupakan salah satu faktor yang dapat mempengaruhi suatu ajaran agama menyebar, tumbuh dan berkembang, suatu realita yang berlangsung pula terhadap ajaran Islam. Ajaran yang dipengaruhi oleh keadaan Mekah dan Madinah dalam membentuk hukum (tasyri'). Keadaan masyarakat Mekah yang sebagian besar adalah pedagang dipengaruhi oleh sentuhansentuhan ayat al-Quran dan al-Hadits yang berkaitan dengan pelaksanaan kegiataan perniagaan yang dilandasi persamaan dan keadilan bagi setiap transaksi yang dilakukan. Keadaan yang berbeda didapatkan di Madinah, komunitas pertanian yang secara khusus memiliki homogenitas masyarakat diarahkan oleh ayat al-Quran dan al-Hadits dengan titik berat pada pembentukan komunitas.

Keadaan yang menarik dari kedua perbedaan etnografi terdapat pada Indonesia, yang mengadopsi kedua keadaan tersebut. Ajaran Islam di Indonesia disebarkan dan berkembang dan bertumbuh bersumber dari kegiatan perniagaan yang dilakukan masyarakat Semenanjung Arab pada 


\section{Fastabiq: Jurnal Studi Islam \\ ISSN 2723-0228}

Volume 1 Nomor 1 Juni 2020

abad $7 \mathrm{M}$, akan tetapi perdagangan tidak mengkerdilkan komunitas pertanian yang secara bersamaan memeluk agama Islam, yang secara bersamaan pula komunitas masyarakat pertanian melakukan perdagangan dengan penyebar agama Islam di wilayah Pantai.

Perpindahan kedua masyarakat Indonesia dipengaruhi oleh Islam sebagai ajaran agama tidak membatasi dan tidak dibuat pembatas antara pemeluknya dengan Allah swt. Islam tidak memerlukan perantara manusia untuk menghubungkan kehendak pemeluknya dalam berkomunikasi dengan Sang Khalik, dan Islam tidak pula mengukur pemeluk-pemeluknya berdasarkan status, kedudukan baik secara sosial, ekomomi maupun politik, melainkan Islam memberikan ukuran yang dapat dipenuhi oleh setiap muslim yaitu ukuran yang menunjukkan penyerahan diri sepenuhnya dengan berdasarkan kepada tuntunan al-Quran dan al-Hadits.

\section{ENDNOTES}

${ }^{1}$ Ajid Thohir, Sirah Nabawiyah (Nabi Muhammad saw dalam Kajian IImu Sosial dan Humaniora), Marja, Bandung, 2014, hlm. 99-100.

2 Firas al-Khateeb, Lost Islamic History Reclaiming Muslim Civilisation From The Past, Hurst Publisher, London, 2014, pg. 1 \& 10.

${ }^{3}$ Maulana Wahiduddin Khan, Muhammad Nabi Untuk Semua (terj. Irwanti), Pustaka Alvabet, Jakarta, 2005, hlm. 15-16.

${ }^{4}$ M. Yunan Yusuf, Implikasi Sosial-Keagamaan Muhammad sebagai Penutup Utusan Allah dalam Kontekstualisasi Doktrin Islam dalam Sejarah, Yayasan Paramadina, Jakarta, 1994, hlm. 537-538. Hadits pada hakikatnya tidak hanya mengandung pemikiran dan pendapat Nabi Muhammad saw saja, melainkanmengandung pula perbuatan serta ketetapannya tentang suatu perkara.

${ }^{5}$ Rahmawati, Islam Di Asia Tenggara, Jurnal Rihlah Vol. II No. 1 2014, hlm. 110.Budaya politik Hindu - Budha yang merupakan tradisi politik wilayah kepulauan telah digantikan dengan ide-ide dan lembaga-lembaga yang diilhami oleh Alquran dan sumber-sumber sah Islam lainnya. Konsep Islam tentang kepemimpinan yang bernafaskan Islam mulai digunakan dan hukum Islam telah dilaksanakan setelah Islam menjadi agama resmi,meskipun tetap selektif. Undang-undang Malaka (dikompilasi tahun 1450) dengan jelas berisi hukum Islam yang menetapkan bahwa pemerintahan Malaka harus dijalankan sesuai dengan hukum Islam.

${ }^{6}$ Asep Achmad Hidayat, Studi Kawasan Muslim Minoritas Asia Tenggara, Pustaka Rahmat, Bandung, 2017, hlm. 11.

${ }^{7}$ Ajid Thohir, Studi Kawasan Dunia Islam: Perspektif Etno-Linguistik Dan Geo-Politik, Rajawali Pers, Jakarta 2011, hlm. 323. Lihat: M. Dahlan M., Dinamika Perkembangan Islam Di Asia Tenggara Perspektif Histori, Jurnal Adabiyah Vol. XIII, No. 1 (2013), hlm. 115. Lihat juga: Fabian Fadhly, Pemahaman Keagamaan Islam di Asia Tengggara Abad XIII-XX, Millah: Jurnal Studi Agama Vol. 18, No. 1 (2018), hlm. 52-53.

${ }^{8}$ Q.S al-'Alaq (96): 1-19

${ }^{9}$ Zacky Khairul Umam, Islam, Arsip, dan Arsipelago: Sebuah Refleksi Keindonesiaan, Jurnal Sejarah - Vol. $1 / 1$ (2017), hlm. 11

${ }^{10}$ Duriana, Islam Di Indonesia Sebelum Kemerdekaan, Dialektika, Vol. 9, No. 2, Januari Desember 2015, hlm, 62.

${ }^{11}$ Mugiyono, Integrasi Pemikiran Islam Dan Peradaban Melayu: Studi Eksploratif Historis Terhadap Perkembangan Peradaban Melayu Islam Di Nusantara, Jurnal IImu Agama (JIA) Juni 2016 Th.17 Nomor 1, hlm. 25.

${ }^{12}$ Tamaddun Vol. 6, No. 2, November 2018, hlm. 134.

${ }^{13}$ Moeflih Hasbullah, Dedi Supriyadi, Filsafat Sejarah, Pustaka Setia, Bandung, 2012, hlm. 256.

${ }^{14}$ Yusuf Sidani, Ibn Khaldun of North Africa: An AD 1377 theory of leadership, Journal of Management History Vol. 14 No. 1, hlm. 76.

${ }^{15}$ Shalih Ahmad ats-Tsamy, Min Ma'in as-Sirah, al-Maktab al-Islamy, Beirut, 1984, hlm. 17. Shafiyu ar-Rahman al-Mubakafury merinci geneologis Nabi Muhammad saw menjadi tiga garis, garis 
pertama terkait dengan nasab Rasullah saw sampai dengan Adnan (Muhammad ibn 'Abdullah ibn 'Abd al-Muthalib ibn Hayim ibn Abdi Manaf ibn Qushay ibn Kilab ibn Murrah ibn Nadra ibn Ka'ab ibn Luay ibn Ghalib ibn Fihr ibn Malik ibn Nadra ibn Kinanah ibn Khuzaimah ibn Mudkirah ibn Ilyas ibn Mudara ibn Nizar ibn Ma'add ibn Adnan. Garis kedua terkait dengan nasab Adnan sampai dengan Nabi Ibrahim as (Adnan Ibn Udad ibn Hamaysa' ibn Salaman ibn 'Aush ibn Bauz ibn Qumwal ibn Abi ibn 'Awam ibn Nasyad ibn Hazan ibn Bildas ibn Yudalaf ibn Thabikh ibn Jahim ibn Nahisy ibn Makha ibn 'Ayidh ibn Abqar ibn 'Ubaid ibn Da'an ibn Hamdan ibn Sinbar ibn Yatsrabi ibn Yahzan ibn Yalhan ibn Ar'awi ibn A'yidh ibn Daisyan ibn 'Ishar Ibnu Afnad ibn Ayham ibn Muqshar ibn Nahits ibn Zarah ibn Sama ibn Muza ibn 'Audlah ibn 'Aram ibn Qidar ibn Ismail ibn Ibrahim as. Garis ketiga terkait dengan nasab Nabi Ibrahim as sampai dengan Nabi Adam as. (Ibrahim as ibn Tarah ibn Nahur ibn Saru' (Sarugh) ibn Ra'u ibn Falah ibn 'Abir ibn Syalakh ibn Arfakhsyad ibn Sam ibn Nuh as ibn Lamak ibn Matusyalakh ibn Akhnukh (Idris as) ibn Yarda ibn Mahlail ibn Qinan ibn Anusy ibn Syits ibn Adam as. (Shafiyu ar-Rahman al-Mubarakafury, Rahiq al-Makhtum Bahtsun as-Sirah anNabawiyyah 'ala Shahibuha Afdhalu as-Shalatu wa as-Salam, Dar al-Wafa, Mansurah, 2002, hlm. 63-64)

16, Sunan Tirmidzi Bab fi Fadhli Nabi Sallallahu ‘alaihi wa SallaM Juz 5, hlm. 584.

${ }^{17} \mathrm{Abu}$ al-Husain Muslim bin al-Hajjaj al-Qusyairi an-Naisaburi, Shohih Muslim Juz IV, al-Maktabah asy-Syamilah, hlm. 1790. Keterangan bahwa Nabi Muhammad saw adalah penutup para Nabi dan Rasul diberikan dalam al-Quran dalam rangkaian firman Allah swt dan ajaran-Nya tentang pembatalan praktek tabanni (mengangkat, kemudian anak itu diakui seperti anak sendiri, seolah benar-benar mempunyai pertalian darah dengan orang tua angkat bersangkutan, dengan konsekuensi kehukuman atau legalnya). Praktek tabanni itu dibatalkan karena tidak sesuai dengan ajaran Islam yang lebih mendalam dan asasi, yaitu ajaran tentang fitrah yang antara lain menghendakisegala sesuatu dinilaiberdasarkan kenyataan instrisiknya, bukan fakta formalnya, dikarenakan tabanni memberikan hak kehukuman kepada seorang anak angkat hanyakarena dirinya dinyatakan sebagai anak sendiri secara lisan (yakni, secara formal), maka parktek itu dianggap tidak fitri. (Nurcholis Madjid, Konsep Muhammad Saw sebagai Penutup para Nabi Implikasi dalam Kehidupan Sosial serta Keagamaan dalam Kontekstualisasi Doktrin Islam dalam Sejarah, Yayasan Paramadina, Jakarta, 1994, hlm.. 527-528).

${ }^{18}$ Faruq Hamadah, Sirah Nabawiyyah (terj. A. Syafiq), Gema Insani Press, Jakarta, 1998, hlm. 20-21.

19 Lihat: Muhammad Husain Haekal, Hayatu Muhammad, Dar al-Ma'arif, Kairo, 1965, hlm. 31. Mustafha al-Maraghy dalam kitab ini menyampaikan Sirah merupakan gambaran dari keindahan, kemuliaan, keagungan, keteladanan yang menenangkan melalui diri Rasulullah saw sebagai manusia yang memiliki dan mengajarkan kebaikan dan mencabut kedzoliman manusia yang telah tertanam selama bertahun-tahun serta menerangin kedzaliman itu dengan cahaya iman.

${ }^{20}$ Lihat. Ali Muhammad Mu'awwid dan 'Adil Ahmad al-Mawjud, Tarikh Tasyr'i Dirastun fi a-Tasyr'i wa Tatuwwirihi wa Rijalihi, Dar al-Kutub al-Ilmiyyah, Beirut, 2000, hlm. 234.

21 Nasikh dan Manskuh dalam risalah Nabi Muhammad saw terkait dengan perubahan-perubahan hukum yang tercantun dalam al-Quran, menyangkut segi materialnya bersifat ekslusif (sharih) dan inklusif (dhimni). Nasikh Sharih langsung menjelaskan manskuhnya misalnya hukum kiblat. Ketentuan yang nasikh (pengganti) ditetapkan secara jelas. Nasikh dhimni tidak memuat penegasan di dalamnya bahwa ketentuan yang mendahuluinya tercabut, tetapi isinya cukup jelas bertentangan dengan ketentuan yang mendahuluinya. Jenis seperti inilah yang banyak ditemukan dalam hukum syari'at. (Ali Yafie, Nasikh Mansukh dalalam al-Quran dalam Kontekstualisasi Doktrin Islam dalam Sejarah, Yayasan Paramadina, Jakarta, 1994, hlm. 46-47)

${ }^{22}$ Abu al-Husain Muslim bin al-Hajjaj al-Qusyairi an-Naisaburi, Shohih Muslim Juz II, al-Maktabah asySyamilah, hlm. 672.

${ }^{23}$ Q.S. al-Baqarah (2): 130-132

${ }^{24}$ Q.S. al-Mudatsir (74): 1-7

25 Ali Muhammad Mu'awwid dan 'Adil Ahmad al-Mawjud, Tarikh Tasyr'i Dirastun fi a-Tasyr'i wa Tatuwwirihi wa Rijalihi, Dar al-Kutub al-Ilmiyyah, Beirut, 2000, hlm. 8.

${ }^{26}$ Muhammad Khudari Bik, Tarikh Tasyr'i al-Islamy, Dar al-Kutub al-Ilmiyyah, Beirut, 2013, hlm. 5 dan 24.

27 Yayan Sopyan, Tarikh Tasyri' (Sejarah Pembentukan Hukum Islam), Gramata, Depok, 2010, hlm. 54 dan 55.

${ }^{28}$ Q.S. Rum (30) : 39 
${ }^{29}$ M. Amien Rais, Cakrawa Islam, Mizan, Bandung, 1991, Bandung, hlm. 19-20.

${ }^{30}$ Q.S. al-Baqarah (2):143.

${ }^{31}$ Abdul Hafiz Sairazi, Kondisi Geografis, Sosial Politik Dan Hukum Di Makkah Dan Madinah Pada Masa Awal Islam, Journal of Islamic and Law Studies Volume 3, Nomor 1, Juni 2019, hlm. 124.

32 Mustafa Ahmad al-Zarqa, Konsep Ibadah Dalam Islam dalam Pesan Islam (terj. Achsin Mohammad), Pustaka, Bandung, 1983, hlm. 127 dan 133..

${ }^{33}$ Djaka Soetapa, Ummah Komunitas Religius, Sosial dan Politis dalam al-Quran, Duta Wacana University Press, Yogyakarta, 1990, hlm. 79-82.

${ }^{34}$ Ahmad Syalabi, Sejarah dan Kebudayaan Islam, Pustaka Al-Husna, Jakarta, 1983, hlm..87-90

${ }^{35}$ Lihat: W. Montgomery Watt, Muhammad, Prophet and Statesman, Oxford University Press,, Oxford, 1964

${ }^{36}$ Ali Musthafa al-Farabi, Tarikh al-Firqu al-Islami wa Nasyatu 'Ilma al-Kalama Inda al-Muslimin, Maktabah al-Akhbalu al-Masharriyah, 1975, hlm. 12

${ }^{37}$ Abu al-Husain Muslim bin al-Hajjaj al-Qusyairi an-Naisaburi, Shohih Muslim Juz II, al-Maktabah asySyamilah, hlm. 1006.

${ }^{38}$ Nasrah, Proses Awal Pembentukan Hukum Islam (artikel), hlm. 3. 1. Peristiwa Martsad Ganawi. Martsad Ganawi adalah utusan Rasulullah Saw. dari Madinah ke Makkah. Setibanya dia di kota tersebut ia dilamar oleh seorang wanita musyrik yang kaya dan cantik, namun Martsad Ganawi tidak segera memberikan putusan karena wanita tersebut belum masuk Islam. Selanjutnya dia melaporkan hal tersebut kepada Nabi Saw. dan turunlah hukum tentang perkawinan antar agama yang melarang perkawinan dengan wanita musyrik begitu juga sebaliknya perempuan beriman yang dinikahi oleh laki-laki musyrik. 2. Peristiwa janda Sa'ad bin Rahi'. Janda ini mempunyai dua orang anak perempuan dan mempunyai warisan dari suaminya. Menurut kebiasaan orang-orang Arab, mereka tidaklah mendapat apa-apa dari warisan tersebut dan beralih kepada saudara laki-laki dari Sa'ad. Maka hal ini diadukan janda Sa'ad kepada Nabi Saw. dan kemudian turunlah ayat hukum tentang warisan. 3. Turunnya ayat Alquran tentang hukum larangan berperang pada bulan-bulan dan tempat-tempat yang diharamkan oleh Swt. untuk berperang.

${ }^{39}$ Abu al-Husain Muslim bin al-Hajjaj al-Qusyairi an-Naisaburi, Shohih Muslim Juz II, al-Maktabah asySyamilah, hlm. 992.

${ }^{40}$ Perintah zakat yang diturunkan pada periode Makkah baru sebatas anjuran untuk berbuat baik kepada fakir miskin dan orang yang membutuhkan bantuan. Sedangkan yang diturunkan pada periode Madinah adalah perintah wajib secara mutlak untuk dilakukan oleh umat Islam. ( Sahri Muhamad, Pengembangan Zakat dan Infak dalam Usaha Meningkatkan Kesejahteraan Masyarakat Avivena, Malang, 1982, hIm. 14)

${ }^{41}$ Abu Su'ud, Islamologi Sejarah, Ajaran, Dan Peranannya Dalam Peradaban Umat Islam, Rineka Cipta, Jakarta, 2003, hlm. 37.

${ }^{42}$ A. Mukti Ali, Memahami Beberapa Aspek Ajaran Islam, Mizan, Bandung, 1991, hlm. 71.

${ }^{43}$ M. Abdurrahman, Dinamika Mayarakat Islam Dalam Wawasan Fikih, Rosda, Bandung, hlm. 4.

${ }^{44}$ Hunt Janin dan Andre Kahlemeyer, Islamic Law The Sharia from Muhammad's Time to Present, McFarland \& Company, Inc., Publishers, Jefferson, North Carolina, 1940, [g. 13. Muslim Fundamentalis mengunguhkan piagam ini sebagi konstitusi pertama di dunia dan membuktikan Islam sebagai pelopor munculnya konstitusi dalam negara, akan tetapi konsep ini ditentang oleh sebagian sejarawan sekuler.

${ }^{45}$ Anonim.

${ }^{46}$ Wael B. Hallaq, The Origins and Evolution of Islamic Law, Cambridge University Press, Cambridge, 2005, pg. 21.

${ }^{47}$ Q.S. al-Maidah (5): 49-50.

${ }^{48}$ Fazlur Rahman, Islam (terj. Ahsin Mohammad), Pustaka, Bandung, 1984, hlm. 91

${ }^{49}$ Abdullahi Ahmed an-Na'im, Dekosntruksi Syari'ah Wacana Kebebasan Sipil, Hak Asasi Manusia dan Hubungan Internasional dalam Islam (Ahmad Suaedy dan Amiruddin Arani), Kerja sama LKIS dengan Pustaka Pelajar, Yogyakarta, 1994, hlm. 28.

${ }^{50}$ Kamaruzzaman Bustamam Ahmad, Contemporary Islamic Thought In Indonesian And Malay World Islam Liberal, Islam Hadhari, and Islam Progresif, Journal Of Indonesian Islam Volume 05, Number 01, June 2011, pg. 93. Pada masa ini yaitu abad 17 buku yang menjadi rujukan pada Kesultanan Islam di tiga kesultaan tersebut didominasi oleh karya Nurdin ar-Raniri dengan kitabnya Sirat alMustaqin, dan Abdul Rauf Singkel dengan bukunya Mir;at at-Tullab. 
${ }^{51}$ Abu Hamid al-Ghzazali di wilayah Asia Tenggara lebih dikenal dengan Imam al-Ghazali penyusun kitab Ihya al-'Ulum ad-Din.

52 Osman Bakar, Islam And The Three Waves Of Globalisation: The Southeast Asian Experience, Islam and Civilisational Renewal Pluto Journals ICR 1.4, pg. 668 \& 669. Dalam pandangan Osman Bakar budaya Melayu tidak hanya memiliki pengaruh di wilayah Melayu tidak hanya berada di wilayah Melayu itu sendiri (inland Southeast Asia), melainkan pula menyebar sampai dengan wilayah Madagaskar, Afrika Selatan, Suriname bahkan ke Amerika Latin

${ }^{53}$ Hasan Muarif Ambary, Sejarah Perkembangan di Indonesia dalam Kebangkitan Islam Dalam Pembahasan, Yayasan Nurul Islam, tt, hlm. 63.

${ }^{54}$ Sirajuddin M, Wacana Penerapan Hukum Islam dalam Tinjauan Politik Hukum Nasional, SosioReligia, Vol. 8, No. 3, Mei 2009, hlm.809.

${ }_{55}$ Hamka, Sejarah Umat Islam IV, Bulan Bintang, Jakarta, 1976, hlm. I38. Hasil seminar menyimpulkan bahwa agama Islam telah berangsur-angsur datang ke Indonesia sejak abadabad pertama Hijriyah atau sekitar abad ke-7 dan 8 Masehi, langsung dari Arab. Di antara para mubaligh Islam pertama ini terdapat orang-orang dari Malabar, Gujarat, dan Persia. Sekalipun mubaligh itu dari Malabar, Gujarat, dan Persia, para mubaligh tersebut hanya singgah sementara dan mereka berasal dari Arab (K.H.O. Gadjahnata, Sri-Edi Swasono, Masuk dan berkembangnya Islam di Sumatera Selatan, Ul-Press, Jakarta, 1986, hlm. 12).

${ }^{56}$ Mugiyono, "Perkembangan Pemikiran Dan Peradaban Islam Dalam Perspektif Sejarah", JIA XIV, No. 1 (Juni 2013), 11.

${ }^{57}$ Anonim.

${ }^{58}$ Ismuha, Islam Dan Masyarakat Aceh dalam Agama dan Perubahan Sosial, Rajawali, 1983. hlm. 5. Poteu Meureuhomdiartikan sebagai Sultan Iskandar Muda yang memiliki kedudukan sebagai pemimpin dan ulama dikarenakan kemampuannya dalam memimpin dan menguasai ilmu-ilmu islam (pen.)

${ }^{59}$ A. Mukti Ali, Alam Pikiran Islam Modern Di Indonesia dan Modern Islamic Thaought In Indonesia, Jajasan Nida, Jogjakarta, 1969, hIm. 5.

${ }^{60}$ Fauzan Saleh, "Education and the Advancement of Cultural Islam: Rebuilding a "Creater Tradition" for Indonesian Islam", in Alef Theria Wasim et.al, Religious Harmony: Problems, Practice and Education, (Yogyakarta, Oais, 2005), 57.

${ }^{61}$ Lihat: Tsuroya Kiswati, Rekonstruksi Metodologis Wacana "Keadilan Gender" Dalam Prespektif Intelektual Muslim Kontemporer, Chapter Seven The Legacy of Islamic Thought: Contribution for the Future, Annual International Confrence On Islamic Studies, (2005), 2035.

${ }_{62}$ M.M, Syarif, Muslim Thought,. Diponegoro, Bandung, tt, hlm. 161-164. 


\section{REFERENSI}

Abdurrahman, M. 2008, Dinamika Mayarakat Islam Dalam Wawasan Fikih, Bandung: Rosda.

Ahmad, Kamaruzzaman Bustamam, 2011 'Contemporary Islamic Thought In Indonesian And Malay World Islam Liberal, Islam Hadhari, and Islam Progresif', Journal of Indonesian Islam Volume 05, Number 01, June 2011.

Ahmad, Khursid, 1983, Islam: Prinsip-Prinsip Dasar Dan Karakteriisti-Karakteristiknya dalam Pesan Islam (terj. Achsin Mohammad), Bandung: Pustaka.

al-Buthi, Muhammad Said Ramadhan, 1999, Fiqh as-Sirah an-Nabawiyyah ma'a Mawjazi at-Tarikh alKhilafat ar-Rasyidin, Kairo: Dar as-Salam.

al-Farabi, Ali Musthafa, 1975, Tarikh al-Firqu al-Islami wa Nasyatu 'IIma al-Kalama 'Inda al-Muslimin, Mesir: Maktabah al-Akhbalu al-Masharriyah.

al-Khateeb, Firas, 2014, Lost Islamic History Reclaiming Muslim Civilisation From The Past, London: Hurst Publisher.

al-Mubarakafury, Shafiyu ar-Rahman, 2002, Rahiq al-Makhtum Bahtsun Fi as-Sirah an-Nabawiyyah 'ala Shahibuha Afdhalu as-Shalatu wa as-Salam, Mansurah: Dar al-Wafa.

ats-Tsamy, 1984, Shalih Ahmad, Min Ma'in as-Sirah, Beirut: al-Maktab al-Islamy.

al-Zarqa, Mustafa Ahmad, 1983, Konsep Ibadah Dalam Islam dalam Pesan Islam (terj. Achsin Mohammad), Bandung: Pustaka.

Ali, A. Mukti, 1969, Alam Pikiran Islam Modern Di Indonesia dan Modern Islamic Thaought In Indonesia, Jogjakarta: Jajasan Nida. 1991, Memahami Beberapa Aspek Ajaran Islam, Bandung: Mizan.

Ambary, Hasan Muarif. Tt. Sejarah Perkembangan di Indonesia dalam Kebangkitan Islam Dalam Pembahasan, Yayasan Nurul Islam.

An-Na'im, Abdullahi Ahmed, 1994, Dekosntruksi Syari'ah Wacana Kebebasan Sipil, Hak Asasi Manusia dan Hubungan Internasional dalam Islam (Ahmad Suaedy dan Amiruddin Arani), Yogyakarta: Kerja sama LKIS dengan Pustaka Pelajar.

an-Naisaburi, Abu al-Husain Muslim bin al-Hajjaj al-Qusyairi, Shohih Muslim Juz IV, al-Maktabah asySyamilah. 
Azzam, Abdurrahman, 1983, Riwayat Hidup Nabi Muhammad, dalam Pesan Islam (terj. Achsin Mohammad), Bandung: Pustaka.

Bakar, Osman, 'Islam And The Three Waves Of Globalisation: The Southeast Asian Experience', Islam and Civilisational Renewal Pluto Journals ICR 1.4.

Bik, Muhammad Khudari, 2013, Tarikh Tasyr'i al-Islamy, Beirut: Dar al-Kutub al-IImiyyah.

Duriana, 2015, 'Islam Di Indonesia Sebelum Kemerdekaan', Dialektika, Vol. 9, No. 2, Januari Desember 2015.

Haekal, Muhammad Husain, 1965, Hayatu Muhammad, Kairo: Dar al-Ma'arif.

Haekal, Muhammad Husain, 1974, Sejarah Hidup Muhammad (terj. Ali Audah), Jakarta: Tinta Mas.

Hallaq, Wael B. 2005, The Origins and Evolution of Islamic Law, Cambridge: Cambridge University Press.

Hamadah, Faruq, 1998, Sirah Nabawiyyah (terj. A. Syafiq), Jakarta: Gema Insani Press.

Hamka, 1976, Sejarah Umat Islam IV, Jakarta: Bulan Bintang.

Hidayat, Asep Achmad, 2017, Studi Kawasan Muslim Minoritas Asia Tenggara, Bandung: Pustaka Rahmat.

Ismuha, 1983, Islam Dan Masyarakat Aceh dalam Agama dan Perubahan Sosial, Jakarta: Rajawali Press.

Janin, Hunt, Andre Kahlemeyer, 1940, Islamic Law The Sharia from Muhammad's Time to Present, North Carolina: McFarland \& Company, Inc., Publishers, Jefferson.

Khan, Maulana Wahiduddin, 2005, Muhammad Nabi Untuk Semua (terj. Irwanti), Jakarta: Pustaka Alvabet.

Landau, Rom, 1958, Islam and Arabs, London: Ruskin Houese (George Allen \& Unwin Ltd).

Madjid, Nurcholis, 1994, Konsep Muhammad Saw sebagai Penutup para Nabi Implikasi dalam Kehidupan Sosial serta Keagamaan dalam Kontekstualisasi Doktrin Islam dalam Sejarah, Jakarta: Yayasan Paramadina.

Mu'awwid, Ali Muhammad, 'Adil Ahmad al-Mawjud, 2000, Tarikh Tasyr'i Dirastun fi a-Tasyr'i wa Tatuwwirihi wa Rijalihi, Beirut: Dar al-Kutub al-Ilmiyyah.

Mugiyono, 2016, 'Integrasi Pemikiran Islam Dan Peradaban Melayu: Studi Eksploratif Historis Terhadap Perkembangan Peradaban Melayu Islam Di Nusantara', Jurnal IImu Agama (JIA) Juni 2016 Th.17 Nomor 1.

Muhamad, Sahri, 1982, Pengembangan Zakat dan Infak dalam Usaha Meningkatkan Kesejahteraan Masyarakat, Malang: Avivena.

Rahman, Fazlur, 1984, Islam (terj. Ahsin Mohammad), Bandung: Pustaka.

Rais, M. Amien, 1991, Cakrawala Islam, Bandung: Mizan.

Rahmawati, 2014. 'Islam Di Asia Tenggara', Jurnal Rihlah Vol. II No. 12014.

Abdul Hafiz Sairazi, 2019. 'Kondisi Geografis, Sosial Politik Dan Hukum Di Makkah Dan Madinah Pada Masa Awal Islam,' Journal of Islamic and Law Studies Volume 3, Nomor 1, Juni 2019.

Soetapa, Djaka, 1990, Ummah Komunitas Religius, Sosial dan Politis dalam al-Quran, Yogyakarta: Duta Wacana University Press.

Sopyan, Yayan, 2010, Tarikh Tasyri' (Sejarah Pembentukan Hukum Islam), Depok: Gramata.

Su'ud, Abu, 2003, Islamologi Sejarah, Ajaran, Dan Peranannya Dalam Peradaban Umat Islam, Jakarta: Rineka Cipta.

Syalabi, Ahmad, 1983, Sejarah dan Kebudayaan Islam, Jakarta: Pustaka Al-Husna. 
Fastabiq: Jurnal Studi Islam

ISSN 2723-0228

Volume 1 Nomor 1 Juni 2020

Syu ban, Zakiyy al-Din, 1988, Usul al-Fiqh al-Islami, Kuwait: Mu`assash `Ali as-Sibah.

Thohir, Ajid, 2011, Studi Kawasan Dunia Islam: Perspektif Etno-Linguistik Dan Geo-Politik, Jakarta: Rajawali Pers.

---, 2014, Sirah Nabawiyah (Nabi Muhammad saw dalam Kajian Ilmu Sosial dan Humaniora), Bandung: Marja.

Yafie, Ali, 1994, Nasikh Mansukh dalalam al-Quran dalam Kontekstualisasi Doktrin Islam dalam Sejarah, Jakarta: Yayasan Paramadina.

Yunan, Yusuf, M. 1994, 'Implikasi Sosial-Keagamaan Muhammad sebagai Penutup Utusan Allah' dalam Kontekstualisasi Doktrin Islam dalam Sejarah, Jakarta: Yayasan Paramadina.

Yusuf, Muhammad, Ismail Suardi Wekke, 'Menelusuri Historisitas Pembentukan Hukum Islam: Menggagas Yurisprudensi Islam Indonesia', Jurnal Tsaqafah, Vol. 8, No. 2, Oktober 2012. 